\title{
Increased procollagenase activating angiogenic factor in the vitreous humour of oxygen treated kittens
}

\author{
C M TAYLOR,' J B WEISS,' B McLAUGHLin,' R D KISSUN, \\ AND A GARNER \\ From the 'Department of Rheumatology, University of Manchester Medical School, Stopford Building, \\ Manchester M13 9PT, and the ${ }^{2}$ Department of Pathology, Institute of Ophthalmology, London WC1
}

SUMmaRY Previous studies have demonstrated an increase in a low molecular weight angiogenic factor (ESAF) present in the retinae of kittens with oxygen induced retinopathy. The present paper describes differences in the quantity of ESAF extracted from the vitreous humour of control and oxygen treated animals and proposes a mechanism for the induction of intravitreal neovascularisation.

The existence of an angiogenic factor in retinal tissue undergoing active vascularisation was first proposed by Michaelson' in 1948. It was suggested that such a factor would be a small freely diffusible molecule, ${ }^{2}$ the release of which could be brought about by hypoxia. ${ }^{3-5}$ Release of such a factor into the vitreous humour and its accumulation therein would bring about the vascularisation of this tissue by retinal vessels.

Retinal extracts have been shown not only to promote angiogenesis in the cornea ${ }^{6}$ and the chick chorioallantoic membrane ${ }^{7}$ but also to contain a low molecular weight endothelial cell angiogenic factor (ESAF).$^{78}$ The quantitative assay of this molecule can be achieved by virtue of its ability to activate skin fibroblast procollagenase in a dose dependent manner, ' and differences in the quantities of ESAF present in normal and oxygen treated retinae have already been described. ${ }^{10}$ Other recent studies have shown ESAF to be present in vitreous humour taken from both normal eyes* and from those with proliferative diabetic retinopathy. $\dagger$ Hence it appears that in conditions of proliferative retinal vascular growth there occur quantitative changes in the ESAF normally present in the retina and vitreous humour, rather than de novo synthesis or release of a diseasespecific angiogenic molecule from the retina.

\footnotetext{
*Taylor CM, Weiss JB. Quantitation of ESAF in a range of mammalian tissue. In preparation.

†Elstow SF, Kissun RD, Schor AM, McLeod, Weiss JB, Garner A. A low molecular mass angiogenic fraction in vitreous from patients with extraretinal neovascularisation. In preparation.

Correspondence to Dr C M Taylor.
}

The absence of intravitreal neovascularisation in the normal eye may be ascribed to endogenous inhibitors of angiogenesis, ${ }^{112}$ which are present in sufficient quantities to inhibit any neovascularisation induced by endogenous angiogenic molecules. One of these vitreal inhibitors has been shown to inhibit collagenase and hence acts in a manner opposing the procollagenase activating action of ESAF. ${ }^{12}$ In pathological conditions, however, sufficient angiogenic molecules may diffuse from the retina to overcome the natural avascularity of the tissue.

In an earlier report ${ }^{10}$ we showed that destruction of the vasculature of the retina, such as to render it hypoxic, gives rise to elevated levels of ESAF within the retina. We now present evidence that this factor is diffusible and passes into the vitreous, where it is the presumed stimulus to the subsequent preretinal angiogenesis.

\section{Materials and methods}

Newborn kittens were incubated for a period of three days in an atmosphere containing $70-80 \%$ oxygen. They were then removed abruptly to normal room air for a period of between nine and 18 days before administration of an excess of pentobarbital and vitrectomy under deep anaesthesia. Normal healthy kittens not exposed to hyperoxia were used as controls.

Vitreous humour from each individual kitten was homogenised for 15 seconds at $4^{\circ} \mathrm{C}$ in an equal volume of $50 \mathrm{mM} \quad \mathrm{NH}_{4} \quad \mathrm{HCO}_{3}$ buffer (pH 7.9) containing $2 \mathrm{M} \mathrm{MgCl}_{2}$ and was clarified by 
centrifugation at $20000 \mathrm{~g}\left(1 \mathrm{~h}, 4^{\circ} \mathrm{C}\right)$. The supernatant was assayed for protein ${ }^{13}$ prior to ultrafiltration on a YM5 filter membrane (5000 Mr exclusion limit) (Amicon Ltd, Stonehouse, Gloucs) with five volumes of bicarbonate buffer.

The ultrafiltrate was reduced by rotary evaporation to a volume of $5 \mathrm{ml}$ and applied to an octodecyl silica column (Analytichem, Harbor City, California). Bound low molecular weight angiogenic material was eluted with methanol.

Assay of angiogenic material for its ability to activate procollagenase was performed according to the method of Weiss et al. ${ }^{9}$ Results were expressed as $\mu \mathrm{g}$ collagen degraded $/ \mathrm{h} / \mathrm{mg}$ protein in the supernatant.

\section{Results}

Extracts of vitreous humour from both control and oxygen treated kittens contained significant quantities of a low molecular mass angiogenic factor. Reverse phase chromatography permitted the isolation of a purified fraction which when applied to a P2 column eluted in a position consistent with ESAF. ${ }^{8}$ This fraction was assayed for its ability to activate procollagenase. From the results (Table 1) it is apparent that vitreous humour from oxygen treated kittens contains significantly increased quantities

Table 1 Activation of procollagenase* by ESAF† present in the vitreous humour of control and oxygen treated kittens

\begin{tabular}{lll}
\hline Experiment & \multicolumn{2}{l}{$\begin{array}{l}\mu g \text { Collagen degraded/h/mg protein in } \\
\text { supernatant }\end{array}$} \\
\cline { 2 - 3 } & Oxygen treated & Control \\
\hline 1 & 2.00 & 0.50 \\
2 & 1.26 & 1.11 \\
3 & 0.51 & 0.26 \\
4 & 1.00 & 0.59 \\
5 & 2.25 & 0.47 \\
6 & 1.61 & 0.09 \\
7 & 1.04 & \\
8 & 0.91 & \\
9 & 0.67 & 0.50 \\
Mean & 1.25 & 0.35 \\
SD & 0.59 & \\
p=0.01 & & 0.59 \\
Mean retinal results & & \\
from Taylor et al. ${ }^{10}$ & 2.24 & \\
\hline
\end{tabular}

Paired vitreous humours from individual kittens were used in each experiment.

*The procollagenase used in the assay had very little intrinsic collagenolytic activity; enzyme without ESAF degraded less than $0.35 \mu \mathrm{g}$ collagen per hour.

tESAF itself in the absence of procollagenase had no effect on the collagen substrate.

$\mathrm{SD}=$ standard deviation. of low molecular weight procollagenase activating material as compared to controls.

Variation within the two groups is likely to reflect individual differences between animals, though a temporal relationship between duration of exposure to a normal atmosphere and the quantities of ESAF present may exist in the oxygen treated group.

These results complement our earlier study of the effects of hypoxia on the angiogenic potential of the developing kitten retina. ${ }^{10}$ The differences between the vitreous humour samples from the oxygen treated and control kittens were smaller than those found in the retinal extracts.

Although the quantities of ESAF in the control vitreous humour and retinae (expressed as $\mu \mathrm{g}$ collagen degraded $/ \mathrm{h} / \mathrm{mg}$ protein) were similar, in the oxygen treated kittens the retinae contained approximately twice as much ESAF as comparable samples of vitreous humour. Hence an imbalance existed between the quantities of ESAF present in the retinae and vitreous humours of oxygen treated kittens.

\section{Discussion}

The concept of tissue hypoxia as a stimulus to angiogenesis is not new,,$^{1417}$ and a hypoxic gradient has been shown to be mandatory for wound healing angiogenesis. ${ }^{18}$

There is also evidence that a similar situation pertains in respect of the retina, but it was largely circumstantial until we demonstrated that artificially induced retinal ischaemia is followed by raised tissue levels of a specific angiogenic fraction (ESAF). ${ }^{10}$ This provides an explanation for the revascularisation of the retina which occurs in newborn kittens subjected to vaso-obliterative doses of oxygen. However, such animals also develop preretinal new vessels, and our findings in the present report support the view that this reflects diffusion of the initially intraretinal factor into the vitreous. It appears, moreover, that the promotion of new vessel growth is a function of opposing influences, since there is, even in control animals, a basal level of ESAF $(0.50 \mu \mathrm{g}$ collagen degraded $/ \mathrm{h} / \mathrm{mg}$ protein). The presence of antiangiogenic substance(s) in the vitreous of other species is well established." 1219 The level of ESAF in the vitreous compares with that found in the retina of the same animals $(0.59 \mu \mathrm{g}$ collagen degraded $/ \mathrm{h} / \mathrm{mg}$ protein), which suggests that there is little obstacle to passage of the factor across the inner limiting membrane of the retina. It may, in passing, be noted that the presence of significant quantities of ESAF in the retina is likely to be a reflection of the normal processes of developmental vascularisation occurring in the neonate kitten at birth. When the level of 
ESAF rises in the retina in response to ischaemia, this creates a diffusion gradient and an increase in vitreal ESAF concentration which may be sufficient to overwhelm the opposing angiogenic inhibitory substances and permit extraretinal neovascularisation.

The sequence of reduced intraretinal circulation, tissue hypoxia, release of ESAF with diffusion into the vitreous, and subsequent preretinal angiogenesis is not confined to the artificially induced situation in kittens but is likely to be relevant in the context of naturally occurring proliferative retinopathy in man. The presence of angiogenic factor in the vitreous has already been observed in respect of diabetic retinopathy ${ }^{2021}$ and certain other non-diabetic conditions associated with preretinal angiogenesis (Elstow SF, et al. in preparation), and its origin from an inadequately perfused retina is entirely consistent with angiographic findings.

\section{References}

1 Michaelson IC. The mode of development of the vascular system of the retina, with some observations on its significance for certain retinal diseases. Trans Ophthalmol Soc UK 1948; 68: 137-80.

2 Ashton N. Retinal vascularization in health and disease. Am J Ophthalmol 1957; 44: 7-17.

3 Ashton N, Ward B, Serpell G. Effect of oxygen on developing retinal vessels with particular reference to the problem of retrolental fibroplasia. BrJ Ophthalmol 1954; 38: 397-432.

4 Wise GN. Retinal neovascularization. Trans Am Ophthalmol Soc 1956; 54: 729-826.

5 Smith R. Thrombotic glaucoma: a clinico-pathological study. Proc Int XVII Congr Ophthalmol 1954. Montreal, New York: 1955, 2: 1164-75.

6 Kissun RD, Garner A. Vasoformative properties of normal and hypoxic retinal tissue. BrJ Ophthalmol 1977; 61: 394-8.

7 Kissun RD, Hill CR, Garner A, Phillips P, Kumar S, Weiss JB. A low molecular weight angiogenic factor in cat retina. $\mathrm{Br} J$ Ophthalmol 1982; 66: 165-9.
8 Elstow SF, Schor AM, Weiss JB. Bovine retinal angiogenesis factor is a small molecule. Invest Ophthalmol Vis Sci 1985; 26: 74-9.

9 Weiss JB, Hill CR, Davis RJ, McLaughlin B, Sedowofia KA, Brown RA. Activation of procollagenase by low molecular weight angiogenesis factor. Biosci Rep 1983; 3: 171-7.

10 Taylor CM, Weiss JB, Kissun RD, Garner A. Effect of oxygen tension on the quantities of procollagenase-activating angiogenic factor present in the developing kitten retina. Br J Ophthalmol 1986; 70: 162-5.

11 Raymond L, Jacobson B. Isolation and identification of stimulatory and inhibitory growth factors in vitreous. Exp Eye Res 1982; 34: 261-8.

12 Taylor CM, Weiss JB. Partial purification of a $5.7 \mathrm{~K}$ glycoprotein from bovine vitreous which inhibits angiogenesis and collagenase activity. Biochem Biophys Res Commun 1985; 133: 911-6.

13 Lowry OH, Rosenbrough NJ, Farr AL, Randall RJ. Protein measurement with the Folin phenol reagent. J Biol Chem 1951; 193: 265-75.

14 Brem S, Cotran R, Folkman J. Tumor angiogenesis: a quantitative method for histological grading. J Natl Cancer Inst 1972; 48: 347-56.

15 Folkman J. Tumor angiogenesis. Adv Cancer Res 1974; 10: 331-58.

16 Goodson WH, Andrews WS, Thakral KK, Hunt TK. Wound oxygen tension of large versus small wounds in man. Surg Forum 1979; 30: 92-5.

17 Gospodarowicz D, Thakral KK. Production of a corpus luteum angiogenic factor responsible for proliferation of capillaries and neovascularisation of the corpus luteum. Proc Natl Acad Sci USA 1977; 75: 847-51.

18 Knighton DR, Silver IA, Hunt TK. Regulation of woundhealing angiogenesis-effect of oxygen gradients and inspired oxygen concentration. Surgery 1981; 90: 262-70.

19 Jacobson B, Dorfman T, Basu PK, Hasany SM. Inhibition of vascular endothelial cell growth and trypsin by vitreous. Exp Eye Res 1985; 41: 581-95.

20 Glaser BM, D'Amore PA, Michels RG. The effect of human intraocular fluid on vascular endothelial cell migration. Ophthalmology 1981; 88: 986-91.

21 Hill CR, Kissun RD, Weiss JB, Garner A. Angiogenic factor in vitreous from diabetic retinopathy. Experientia 1983; 39: 583-5.

Accepted for publication 27 November 1986. 